\title{
Activity Based Costing Implementation to Determine MSME's Cost Production
}

\author{
Angga Setiawan ${ }^{1}, 2^{\text {nd }}$ Reswanda $^{2}$ \\ Narotama University, Surabaya \\ anggasetiawan2014@gmail.com
}

\begin{abstract}
MSME's are proven capable to survive after the crisis that occurred to maintain sustainability. In this global era, one of them is controlling costs, This study aims to determine the Cost Production of MSME's Wader dan Olahan Sambal Bu Gito Surabaya located at Jl.Sidorukun 2 no.41, Surabaya for one month using the Activity Based Costing method to be more accurate in tracking Factory Overhead Costs based on activities related to production, this study used qualitative methods with a case study approach. The results of the study show that for Wader Original shows conditions under cost $(6,05 \%)$, and for Wader Rempah Pedas, the same conditions are under cost (13,85\%) compared to using traditional system. thus the use of $\mathrm{ABC}$ as a method of determining the cost production is more accurate, and can be applied by the company as a consideration making policies for the progress of companies and cost control procedures
\end{abstract}

Keywords : ABC, MSME's, traditional system, Activity Based Costing

\section{INTRODUCTION}

MSME's (Micro, Small and Medium Enterprises) are one of the pillars of the Indonesian economy which have an important role in the Indonesian economy, both in terms of business numbers and in terms of job creation, this sector is able to absorb a large number of workers in Indonesia with a low cost structure. MSMEs themselves are proven to be able to survive in various post-crisis situations that occur on a national scale (Sudaryanto, 2014) and globally and become the economic driving force for the country of Indonesia. As one of the drivers of the Indonesian economy, MSME's still face many internal and external obstacles, limited working capital, low human resources, and minimal knowledge of technology (Sudaryanto dan Hanim, 2002) Its external factor with the enactment of AFTA (ASEAN Free Trade Area) makes it easier for foreign products to enter Indonesia at low prices and the numbers which are increasingly pounding the domestic market to make price competition tighter and become a potential danger for the presence of MSMEs. MSMEs, combined with managers and regulators in the marketing order so that the worst thing does not happen is that many MSMEs will go bankrupt which results in a long line of unemployment in Indonesia and is feared to result in the next volume of monetary crisis.

The cost management system is expected to be the answer in managing the sustainability of a business or company where this system is designed to provide both complete and financial information, if every MSME is able to apply a detailed system it is not impossible for MSME actors to develop rapidly in the System own cost management there are many aspects in determining progress in financing arrangements and as an alternative in making decisions made by organizations or companies

Cost of Production is an accumulation of costs charged by a product or service (Susilawati \& Anton, 2009). The cost of production is an important basic element as a foundation for the company to

Activity Based Costing Implementation to Determine MSME's Cost Production

Angga Setiawan, Reswanda 
compete with competitors by paying attention to the quality and benefits to be gained so that the company can get maximum profits.

Activity-based costing ( $\mathrm{ABC}$ ) is a system of calculating costs by emphasizing activity as a basic cost object. Activity-based costing $(\mathrm{ABC})$ improves indirect power more accurately than traditional cost items is also used to improve the accuracy of cost analysis by improving the way tracking costs to cost objects. Activity-based costing (ABC) is then presented as a means for SMEs to achieve cost savings and transparency in their operations that can help achieve competitiveness in the global market (Foroughi, Kocakulah, Stott, \& Manyoky, 2017).

In Surabaya, there is one of the MSMEs engaged in processed food business, namely "Wader and Olahan Sambal Bu Gito Surabaya", which started from the beginning until now, still uses the traditional system in determining the cost of production. With the system that has been running so far, will this MSME's be able to set the ideal cost of production and good control for its business, therefore from the above problems researchers are very interested in conducting this research by trying several steps using a comparison with traditional system methods and activity based costing to determine the effectiveness of the company with the best method of determining the Cost of Production

\section{LITERATURE REVIEW}

In determining the Cost of Production according to [5] is a system designed to provide information for management to identify opportunities for improvement, strategic planning, and making operational decisions regarding the procurement and use of resources needed by the organization, and according to researchers Cost management systems are defined as systems designed for management to be able to identify, collect, measure and convey information to management related to planning, control, periodic repairs and as a medium for making decisions in an organization. benefits can help management in planning, controlling, increasing cost traceability, helping management in the investment process, integrating between performance measurement criteria with financial performance calculate the level of automation and various types of philosophy of arrangement and as a decision-making tool. As for the cost is a price sacrifice in order to obtain income that will be used as a reduction in income, and the Cost of Production is all costs used to process a raw material to become finished goods in a certain period of time (Wijayanti, n.d.) while the elements of cost of production according to (Carter \& Usry, 2009) three things include direct material costs, direct labor costs, factory overhead costs, while factory overhead costs are indirect (helper) material costs, indirect labor and all costs other factories that can be clearly defined or charged directly to specific orders, products or other cost objects. Elements factory overhead costs (Alannita \& Suryana, 2014) : Helper Material Costs, Repair and Maintenance Costs, Indirect Labor Costs, As a Result of Assessment of Fixed Assets, Incurred Costs As a Result of Time Passing, Other Overhead Costs that Directly Need Cash Expenditures Researchers will deepen traditional Systems and Activity Based Costing, Understanding Traditional Systems is the measurement of allocation that uses the basis relating to production volume regarding Factory Overhead Costs According to (Abdul Halim, 1999) It can be concluded that the Traditional System is a system of determining the Cost of Production which uses the basis of the imposition of costs in accordance with changes in units or the volume of products produced (Tunggal, 1993) It is easy to be audited because the number of Cost Drivers is not too complex which will make it easier for auditors to carry out the audit process and very easy to implement because they rarely use Cost Driver in allocating it in factory Overhead costs so that managers or owners are easier to monitor while weaknessing Traditional Systems (Supriyono, 1999) as follows: Offer is difficult to explain because there is a distortion of costs, the selling price offered to consumers is too large compared to competitors because the product with a large volume is charged too much per unit cost. The price demanded by consumers for a large volume of products may have been profitable, but was rejected by the company because the cost per unit was distorted too high. Furthermore, the calculation of ActivityBased Costing method focuses on activity as a fundamental cost object (Mulyadi, 2003) (Mathius Tandiontong dan Ardisa Lestari, 2011) states that the definition of Activity Based Costing is an information system oriented to providing complete information about activities to enable company

Activity Based Costing Implementation to Determine MSME's Cost Production

Angga Setiawan, Reswanda 
personnel to manage activities. This information system uses activities as a basis and reduces costs and determines accurately the cost of the product or service as a destination. The following are the procedures carried out in the application of Activity-Based Costing (Supriyono, 1999):

a. In the first stage the activity of determining the base price includes four steps as follows:

Identifying activities, imposing costs on activities, determining groups - homogeneous cost pools, summing activity costs grouped to define groups of similar costs, determination of Overhead group rates (pool rate)

\section{b. Second stage procedure}

In the second stage, the costs of each overhead pool are traced back to production. This is done by using the pool rates calculated in the first stage and by measuring the number of sources used by each production result.

Benefits of Activity-Based Costing for use as a method in determining the cost of production according to [5] including: Determining product costs more accurately, improving the quality of decision making, perfecting strategic planning, enhancing better ability to manage activities through continuous improvement. Directing the organization to be oriented to operations or activities, Using performance measures that, consistent with strategic objectives, Focus on the future of the organization Produce benefits that are far greater than the costs, Identifying the causes of costs (cost driver). Cost Driver According to [13] the basis of allocation used in Activity-based Costing system which are the factors that determine how much or how much effort and workload are needed to carry out an activity. Cost drivers are factors that cause activity costs, Cost Drivers can be measured factors that are used to charge costs to activities and from one activity to another. Cost drivers in the Activity-Based Costing (ABC) cost system use several types of cost triggers while in traditional cost systems only use one type of trigger for certain costs. Based on the type there are resource drivers (Resource Drivers) and Activity Drivers, in the selection of Cost Drivers must be considered Measurement Costs (Cost of Measurement), Correlation Level (Degree of Corelation) between Cost Driver and Consumption, Behavioral Effects.

\section{METHODS}

The type of research used in this study is qualitative research. With the aim of research that intends to understand the phenomena that will be experienced by the subject of research such as perception, action, motivation, behavior and others holistically both by describing in the form of words and languages, special matters that are natural by utilizing natural methods (Moleong, 2007) Qualitative research has a character that is descriptive, namely research in solving problems based on existing data. present data, analyze and interpret it The research approach used is the Case Study approach, [15] case studies are a description and comprehensive explanation of the aspects of an individual, a group, an organization (community), a program, or a social situation. And this research will focus on the calculation of Cost of Production with the traditional system method and Activity-Based Costing system as for the place and time the research was conducted on MSME's Wader and Olahan Sambal Bu Gito Surabaya jl. Sidorukun 2 no. 41, Surabaya, with the time of implementation during December 2018 The subject of this research is the Cost of Production, and the thing that is the object of Activity based-Costing research and the system of Cost of Production in Traditional with the data needed to determine the Cost of Production at Original wader products and spicy waders, data needed qualitatively and quantitative data, while data collection methods are File Research, Library Resesarch, Internet Searching

steps that must be taken :

\section{Identify activities in Traditional Systems}

Calculating Cost of Production by summing Raw Material Cost, Direct Labor Cost , Factory Overhead Cost budgeted by dividing the amount of product units produced by summing the number of production units wader original dan wader rempah pedas.

Activity Based Costing Implementation to Determine MSME's Cost Production

Angga Setiawan, Reswanda 


\section{Identifying activities in Activity Based-Costing}

First stage procedure :

At this stage there are 5 steps that need to be done according to (Supriyono, 1999) is :

1) Identifying activities as for activities in making waders are: cleaning, processing, frying, finishing, shipping (Memperoleh, Sarjana, Universitas, Semarang, \& Saputri, 2013).

2) Charging costs to activities Costs incurred in the production process of waders include: Helper costs, water costs, electricity costs, labeling costs, packaging costs, shipping costs, and telephone costs

3) Grouping similar activities to form a kind of group (homogeneous).

4) Summing up activity costs which are grouped to define similar cost groups (homogeneous cost pool).

5) Calculating the group overhead rates

Factory Overhead Cost per activity group $:$ Factory Overhead Cost group of certain activities Cost Driver

The second stage procedure is :

Charges group rates based on the Cost Driver used to calculate the Factory Overhead Cost charged. Fees for each group Factory overhead costs are tracked to various types of products. Factory Overhead Cost is determined from each cost group to each product with the following formula

Factory Overhead Cost is charged $=$ group rates $\chi$ driver unit used

\section{RESULT}

MSMEs Wader dan Olahan Sambal Bu Gito Surabaya is a MSMEs that deals with food production and processed sambal with various variants, cooperating with the Surabaya Industry and Trade Office (Disperindag) in other words Mrs. Gito becomes MSMEsassisted by Ministry of Industry and Trade which is headquartered at Tunjungan Center or widely known as Siola Building with East Java Cooperative and MSME Office where the quality of its products, especially Crispy or Original Wader (Crunchy Fish), is often brought to the national scale UMKM exhibitions held in major cities in Indonesia His greatest achievements have penetrated the export market to overseas including Japan and Taiwan. And all the products sold and produced by Mrs. Gito are all without using preservatives at all, Mrs. Gito's motto that attracts researchers is "I have a product and you have to sell it"

Table 1 Amount of Raw Material Costs Wader Original and Wader Rempah Pedas

\begin{tabular}{ccrrrr}
\hline No. & Types of products & $\begin{array}{c}\text { Amount } \\
(\mathrm{Kg})\end{array}$ & $\begin{array}{c}\text { Total Price } \\
(\mathrm{Rp})\end{array}$ & $\begin{array}{c}\text { Cost Delivery / } \\
\text { kilogram(Kg) }\end{array}$ & $\begin{array}{c}\text { Amount of } \\
\text { Raw Material } \\
(\mathrm{Rp})\end{array}$ \\
\hline 1 & Wader Original & 800 & 21.600 .000 & 800.000 & 22.400 .000 \\
\hline 2 & $\begin{array}{c}\text { Wader Rempah } \\
\text { Pedas }\end{array}$ & 300 & 8.100 .000 & 300.000 & 8.400 .000 \\
\hline
\end{tabular}




$\begin{array}{lll}\text { Amount } \quad 1.100 \mathrm{Kg} & 30.800 .000\end{array}$

Source: MSME's data, data processed 2019

Table 2 Amount of Direct Labor Costs MSME's Wader dan Olahan Sambel Bu Gito Surabaya

\begin{tabular}{rcccc}
\hline NO. & Types of products & $\begin{array}{c}\text { Unit production } \\
(\mathrm{PCS})\end{array}$ & $\begin{array}{c}\text { Raw material costs } \\
(\mathrm{Rp})\end{array}$ & $\begin{array}{c}\text { Direct Labor } \\
\text { Costs }\end{array}$ \\
\hline 1 & Wader Original & 1770 & $\mathrm{Rp} 22.400 .000$ & $\mathrm{Rp} 4.650 .000$ \\
\hline 2 & Wader Rempah Pedas & 600 & $\mathrm{Rp} 8.400 .000$ & $\mathrm{Rp} 1.190 .000$ \\
\hline Amount & 2370 & $\mathrm{Rp} \mathrm{30.800.000}$ & $\mathrm{Rp} 5.840 .000$
\end{tabular}

Source: MSME's data, data processed 2019

Table 3 Factory Overhead Cost MSME's Wader dan Olahan Sambal Bu Gito Surabaya

\begin{tabular}{|c|c|c|}
\hline No. & Information & Amount (Rp) \\
\hline 1 & Cost of Helper material & Rp 10.564 .000 \\
\hline 2 & Shipping Costs & 250.000 \\
\hline 3 & Cost Of Water & 150.000 \\
\hline 4 & Electricity cost & 552.147 \\
\hline 5 & Telephone Charges & 110.000 \\
\hline 6 & Labeling Costs & $\begin{array}{ll}\mathrm{Rp} & 1.067 .000\end{array}$ \\
\hline 7 & Packaging Costs & $\begin{array}{ll}\mathrm{Rp} & 3.894 .000\end{array}$ \\
\hline 8 & Oil Fuel Costs & 150.000 \\
\hline
\end{tabular}

Source: MSME's data, data processed 2019

\section{Calculation of Cost of Goods production using a traditional system}

The cost of production of Wader Bu Gito still uses traditional systems combining, among others, raw material costs, direct labor costs and factory overhead costs are multiplied by the costs used by each product, Factory Overhead Cost wader dan olahan sambal Bu Gito as big as Rp. 16.737.147,00 and the product produced by Mrs. Gito is 2,370 units, the following is the calculation of the cost of production using a traditional method or system.

Factory Overhead Cost: $\frac{\text { Factory Overhead Cost group of certain activities }}{\text { Cost Driver }}$

Factory Overhead Cost $=\frac{16.737 .147}{2370 \text { Unit }}=7.062,09 /$ unit

Table 4 Cost of Production of Wader Original Per Unit With traditional system methods

Wader Original 
:: IJIEEB ::

(International Journal of Integrated Education, Engineering and Business)

Volume 1 Number 2 September 2018

This work is licensed under a Creative Commons Attribution-ShareAlike 4.0 International License.

\begin{tabular}{l|rr|c|cr}
\hline \multicolumn{1}{c|}{ Cost Element } & \multicolumn{2}{c|}{ Total cost } & Amount & \multicolumn{2}{c}{ Cost per unit (Rp) } \\
\hline Main Cost & Rp & 27.050 .000 & 1770 & $\mathrm{Rp}$ & $15.282,49$ \\
\hline $\begin{array}{l}\text { Factory Overhead Cost } \\
\text { (Rp.7.062,09x 1770) }\end{array}$ & $\mathrm{Rp}$ & 12.499 .899 & 1770 & $\mathrm{Rp}$ & $7.062,09$ \\
\hline & $\mathrm{Rp}$ & 39.549 .899 & & $\mathrm{Rp}$ & $22.344,58$ \\
\hline
\end{tabular}

Source: Data that has been processed

Table 5 Cost of Production of Original Wader Per Unit With traditional system methods

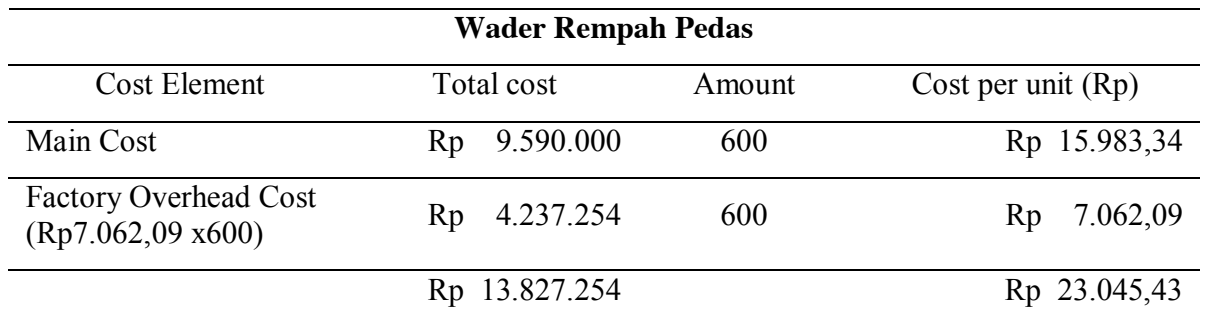

Source: Data that has been processed

Calculation Using Activity Based Costing Wader Original and Wader Rempah Pedas

Table 6 Amount of Raw Material Costs Wader Original and Wader Rempah Pedas

\begin{tabular}{ccccc}
\hline NO. & Types of products & Unit production (PCS) & \multicolumn{2}{c}{ Raw Material Costs (Rp) } \\
\hline 1 & Wader Original & 1770 & Rp 22.400 .000 \\
\hline 2 & Wader Rempah Pedas & 600 & Rp & 8.400 .000 \\
\hline Amount & 2370 & Rp 30.800 .000
\end{tabular}

Table 7 Direct Labor Costs Original dan Wader Rempah Pedas

\begin{tabular}{rlrrr}
\hline \multirow{2}{*}{ NO. } & \multirow{2}{*}{ Procces } & Total direct labor & \multicolumn{1}{c}{$\begin{array}{c}\text { Total direct labor } \\
\text { cost (Rp) }\end{array}$} & \multicolumn{2}{c}{$\begin{array}{c}\text { Total direct labor cost } \\
\text { (Rp) }\end{array}$} \\
\cline { 4 - 6 } & & & Wader Original & Wader Rempah Pedas \\
\hline 1 & Cleaning & 2 & 940.000 & 160.000 \\
\hline 2 & Frying & 1 & 1.790 .000 & 400.000 \\
\hline 3 & ovening & 2 & 500.000 & 300.000 \\
\hline 4 & Finishing & 6 & 1.420 .000 & 330.000 \\
\hline & Amount & 6 & 4.650 .000 & 1.190 .000
\end{tabular}


:: IJIEEB ::

(International Journal of Integrated Education, Engineering and Business)

Volume 1 Number 2 September 2018

Determination Factory Overhead Cost

Table 8 Total Cost of Helper material Wader Original dan Wader Rempah Pedas

\begin{tabular}{rlrrr}
\hline N0. & Cost of Helper material & $\begin{array}{c}\text { Wader } \\
\text { Original }\end{array}$ & $\begin{array}{c}\text { Wader Rempah } \\
\text { Pedas }\end{array}$ & Amount (Rp) \\
\hline 1 & Cooking oil & 6.632 .000 & 2.182 .000 & 8.814 .000 \\
\hline 2 & Seasoning concoction & 1.050 .000 & 200.000 & 1.250 .000 \\
\hline 3 & Spices & & 400.000 & 400.000 \\
\hline 4 & Chili powder & & 100.000 & 100.000 \\
\hline & Amount & 7.682 .000 & 2.882 .000 & 10.564 .000
\end{tabular}

Source: Data that has been processed

Table 9 Factory Overhead Cost MSME's Wader dan Olahan Sambal Bu Gito Surabaya

\begin{tabular}{|c|c|c|}
\hline No. & Information & Amount (Rp) \\
\hline 1 & Cost of Helper material & $\mathrm{Rp} \quad 10.564 .000$ \\
\hline 2 & Shipping Costs & 250.000 \\
\hline 3 & Cost Of Water & 150.000 \\
\hline 4 & Electricity cost & 552.147 \\
\hline 5 & Telephone Charges & 110.000 \\
\hline 6 & Labeling Costs & $\mathrm{Rp} \quad 1.067 .000$ \\
\hline 7 & Packaging Costs & $\begin{array}{ll}\mathrm{Rp} & 3.894 .000\end{array}$ \\
\hline 8 & Oil Fuel Costs & 150.000 \\
\hline & Amount & Rp 16.737 .147 \\
\hline
\end{tabular}

Source: Data that has been processed

Table 10 Implement the costs of similar groups Wader Original and Wader Rempah Pedas

\begin{tabular}{|c|c|c|c|c|}
\hline \multirow[t]{2}{*}{ NO } & \multirow{2}{*}{ Activity group } & \multirow{2}{*}{ Type of cost } & Wader Original & $\begin{array}{l}\text { Wader Rempah } \\
\text { Pedas }\end{array}$ \\
\hline & & & Amount (Rp) & Amount (Rp) \\
\hline \multirow[t]{2}{*}{1} & Cleaning & Air & 150.000 & 150.000 \\
\hline & & Amount & 150.000 & 150.000 \\
\hline \multirow[t]{2}{*}{2} & Frying & $\begin{array}{l}\text { Cost of Helper } \\
\text { material }\end{array}$ & 7.682 .000 & 2.882 .000 \\
\hline & & Amount & 7.682 .000 & 2.882 .000 \\
\hline 3 & ovening & Electricity cost & 552.147 & 552.147 \\
\hline
\end{tabular}

Activity Based Costing Implementation to Determine MSME's Cost Production

Angga Setiawan, Reswanda 
:: IJIEEB ::

(International Journal of Integrated Education, Engineering and Business)

Volume 1 Number 2 September 2018

\begin{tabular}{|c|c|c|c|c|}
\hline & & Amount & 552.147 & 552.147 \\
\hline \multirow[t]{3}{*}{4} & Finishing & Labeling Costs & 1.067 .000 & 1.067 .000 \\
\hline & & Packaging Costs & 3.894 .000 & 3.894 .000 \\
\hline & & Amount & 4.961 .000 & 4.961 .000 \\
\hline \multirow[t]{4}{*}{5} & Delivery & Oil Fuel Costs & 120.000 & 120.000 \\
\hline & & Shipping Costs & 200.000 & 200.000 \\
\hline & & Biaya Telepon & 70.000 & 70.000 \\
\hline & & Amount & 390.000 & 390.000 \\
\hline
\end{tabular}

Source: Data that has been processed

\section{Table 11 Cost Driver}

\begin{tabular}{cccc}
\hline Cost Driver & Wader Original & Wader Rempah pedas & Total \\
\hline $\begin{array}{c}\text { Amount of raw materials } \\
(\mathrm{KG})\end{array}$ & $800 \mathrm{Kg}$ & $300 \mathrm{Kg}$ & $1100 \mathrm{Kg}$ \\
\hline Number of production units & $1770 \mathrm{Pcs}$ & $600 \mathrm{Pcs}$ & $2370 \mathrm{Pcs}$ \\
\hline Electricity Costs (KWh) & $259 \mathrm{KWh}$ & $91 \mathrm{KWh}$ & $360 \mathrm{KWh}$ \\
\hline Water Fee $^{3}$ & $35 \mathrm{M}^{3}$ & $15 \mathrm{M}^{3}$ & $50 \mathrm{M}^{3}$ \\
\hline
\end{tabular}

Source: Data that has been processed

Factory Overhead Cost per activity group : Factory Overhead Cost group of certain activities Cost Driver

\section{Factory Overhead Cost is charged = group rates $\chi$ driver unit used}

Table 12 Total Allocated Overhead Costs Wader Original and Wader Rempah Pedas the Costing Activity Bases Method

\begin{tabular}{|c|c|c|c|}
\hline \multirow{2}{*}{ No. } & \multirow{2}{*}{ Activity group } & Wader Original & Wader Rempah Pedas \\
\hline & & Amount (Rp) & Amount (Rp) \\
\hline 1 & Cleaning & 109.091 & 40.911 \\
\hline 2 & Frying & Rp $\quad 5.586 .912$ & 786.000 \\
\hline 3 & ovening & 412.577 & 139.571 \\
\hline 4 & Finishing & Rp $\quad 3.705 .053$ & 1.255 .950 \\
\hline 5 & Delivery & $\begin{array}{ll}\mathrm{Rp} & 291.272\end{array}$ & 98.736 \\
\hline
\end{tabular}

Source: Data that has been processed 
Table 13 Calculation Cost Of Oroduct Per Unit Wader Original and Wader Rempah Pedas Using Activity-Based Costing

\begin{tabular}{lrr}
\hline \multicolumn{1}{c}{ Information } & Wader Original & \multicolumn{1}{c}{ Wader Rempah Pedas } \\
\hline RMC (Rp) & 22.400 .000 & 8.400 .000 \\
\hline DLC (Rp) & 4.650 .000 & 1.190 .000 \\
\hline FOC (Rp) & 10.104 .905 & 2.321 .168 \\
\hline COP (Rp) & 37.154 .905 & 11.911 .168 \\
\hline Unit & 1770 & 600 \\
\hline HPP / unit (Rp)(Rounding) & 20.992 & 19.852
\end{tabular}

Source: Data that has been processed 


\begin{tabular}{|c|c|c|c|c|c|c|c|c|c|}
\hline \multirow{2}{*}{$\begin{array}{l}\text { types of } \\
\text { products }\end{array}$} & \multirow[b]{2}{*}{ Unit } & \multirow{2}{*}{$\begin{array}{l}\text { BBB } \\
\text { (Rp) }\end{array}$} & \multirow{2}{*}{$\begin{array}{l}\text { BTK } \\
\text { (Rp) }\end{array}$} & \multicolumn{2}{|c|}{$\begin{array}{l}\text { Activity-Based } \\
\text { Costing }\end{array}$} & \multicolumn{2}{|c|}{ Traditional } & \multicolumn{2}{|c|}{ diferrent } \\
\hline & & & & $\begin{array}{l}\text { BOP } \\
(\mathrm{Rp})\end{array}$ & $\begin{array}{l}\text { HPP } \\
(\mathrm{Rp})\end{array}$ & $\begin{array}{l}\text { BOP } \\
(\mathrm{Rp})\end{array}$ & $\begin{array}{l}\text { HPP } \\
(\mathrm{Rp})\end{array}$ & $\begin{array}{l}\text { HPP } \\
\text { (Rp) }\end{array}$ & $\begin{array}{c}\text { HPP / } \\
\text { Unit } \\
(\mathrm{Rp})\end{array}$ \\
\hline $\begin{array}{c}\text { Wader } \\
\text { Original }\end{array}$ & 1770 & $\begin{array}{r}22.400 . \\
000\end{array}$ & $\begin{array}{r}4.650 . \\
000\end{array}$ & $\begin{array}{r}10.104 . \\
905\end{array}$ & $\begin{array}{r}37.154 . \\
905\end{array}$ & $\begin{array}{r}12.499 . \\
899\end{array}$ & $\begin{array}{r}39.549 . \\
899\end{array}$ & $\begin{array}{r}2.394 . \\
994\end{array}$ & $\begin{array}{r}1.353, \\
01\end{array}$ \\
\hline $\begin{array}{c}\text { Wader } \\
\text { Rempah } \\
\text { Pedas }\end{array}$ & 600 & $\begin{array}{r}8.400 .0 \\
00\end{array}$ & $\begin{array}{r}1.190 . \\
000\end{array}$ & $\begin{array}{r}2.321 .1 \\
68\end{array}$ & $\begin{array}{r}11.911 . \\
168\end{array}$ & $\begin{array}{r}4.237 .2 \\
54\end{array}$ & $\begin{array}{r}13.827 . \\
254\end{array}$ & $\begin{array}{r}1.916 . \\
086\end{array}$ & $\begin{array}{r}3.193 \\
48\end{array}$ \\
\hline
\end{tabular}

Source: Data that has been processed

Table 14 above is the Comparison of Principal Prices of Wader Original and Wader Rempah Pedas Between Activity-Based Costing and Traditional Systems

Table 15 Results of Comparison of Cost of Production per Unit between the Activity-Based Costing Method and the Traditional System

\begin{tabular}{lrrrrr}
\hline types of products & $\begin{array}{l}\text { Sistem } \\
\text { ABC }\end{array}$ & $\begin{array}{l}\text { Sistem } \\
\text { traditional }\end{array}$ & diferrent & $\%$ & value condition \\
\hline Wader Original & 20.992 & 22.345 & 1.353 & 6,05 & Under Cost \\
\hline Wader Rempah Pedas & 19.852 & 23.046 & 3.194 & 13,85 & Under Cost \\
\hline Source: Data that has been processed
\end{tabular}

\section{CONCLUSION}

Based on the research and discussion that the researchers did on the Wader UMKM and Olahan Sambal Bu Gito Surabaya, it can be concluded that:

Currently the Wader UMKM and Olahan Sambal Bu Gito Surabaya in calculating the Cost of Production still use a traditional system where factory Overhead Costs only use a single tariff, namely the number of units produced so that many costs are calculated loss and cost distortion occurs. two stages, namely the first stage includes identifying and classifying activities including cleaning activities, frying, oven, finishing, shipping. determine the right Cost driver for each activity, determine the group of similar costs (homogeneous cost pool), determine group rates (Pool Rate), the second stage is to charge group rates based on Cost Driver. Cost Driver used is the number of units, electricity costs, the amount of raw materials and water costs so that the allocation of activity costs to each product produced is more accurate and minimal distorsi loading of overhead costs. so that cost control can be maximized. In the calculation of the Traditional System the results of the Cost of Production per unit for Original Wader are Rp. 22.345,00 and Wader Rempah Pedas of Rp. 23.046,00 .In the calculation of Activity Based Costing System, the following results are obtained as Original Wader of Rp. 20.992,00 and Wader Rempah Pedas of Rp.19.852,00, the difference between Wader Original is Rp. 1.353,00 per unit or 6,05\% compared to the Traditional method, Wader Remph Pedas are cheaper Rp. 3.194,00 or 13,85\% . MSMEs and Olahan Sambal Bu Gito Surabaya can use the Activity-Based Costing method, because this method is more accurate in allocating Factory Overhead Costs based on a number of Cost Drivers, so that the traceability of costs is maximal, and can be applied in small businesses, the Cost of Production is the company's strategy in determining the nominal price of products sold by calculating profit margins. For further 
research using Activity-Based Costing can be applied to non-production or manufacturing companies such as Hotels, Hospitals, and also suits a. so that the information provided is more varied and can increase the capabilities of MSME Entrepreneur (Amir, Auzair, \& Amiruddin, 2016)

\section{REFERENCES}

Abdul Halim. (1999). Dasar-dasar Akuntansi Biaya. Edisi Keempat, Cetakan Ketiga, Yogyakarta: BPFEUniversitas Gajah Mada.

Alannita, N. P., \& Suryana, N. A. S. (2014). Pengaruh Kecanggihan Teknologi Informasi, Partisipasi Manajemen, Dan Kemampuan Teknik Pemakai Sistem Informasi Akuntansi Pada Kinerja Individu. Jurnal Akuntansi Universitas Udayana, 33-45.

Amir, A., Auzair, S. M., \& Amiruddin, R. (2016). Cost Management, Entrepreneurship and Competitiveness of Strategic Priorities for Small and Medium Enterprises. Procedia - Social and Behavioral Sciences, 219, 84-90. https://doi.org/10.1016/j.sbspro.2016.04.046

Carter, W. K., \& Usry, M. F. (2009). Akuntansi biaya. Jakarta: Salemba Empat.

Foroughi, A., Kocakulah, M., Stott, A., \& Manyoky, L. (2017). Activity-Based Costing: Helping Small and Medium-Sized Firms Achieve a Competitive Edge in the Global Marketplace. Research in Economics and Management, 2(5), 150. https://doi.org/10.22158/rem.v2n5p150

Mathius Tandiontong dan Ardisa Lestari. (2011). Akurat Jurnal Ilmiah Akuntansi Nomor 05 Tahun ke-2 Mei-Agustus 2011.

Memperoleh, U., Sarjana, G., Universitas, P., Semarang, N., \& Saputri, H. E. (2013). ANALISIS PENENTUAN HARGA POKOK PRODUKSI TAS BERDASARKAN SISTEM ACTIVITY BASED COSTING PADA PERUSAHAAN TAS MONALISA.

Moleong, L. J. (2007). Metodologi Penelitian Kualitatif edisi revisi Bandung: PT Remaja Rosdakarya Offset. ISBN 979-514-051-5.

Mulyadi. (2003). Activity Based Costing System: Sistem Informasi Biaya untuk Pengurangan Biaya (Edisi 6). Yogyakarta: UPP AMP. YKPN.

Mulyana, D. (2010). Metode Penelitian Kualitatif (Cet. VII, Bandung: PT. Remaja Rosdakarya.

Panekenan, I., \& Sabijono, H. (2014). Penerapan Metode Activity Based Costing Dalam Menentukan Besarnya Tarif Jasa Inap Pada Penginapan Vili Calaca Manado. Jurnal EMBA: Jurnal Riset Ekonomi, Manajemen, Bisnis Dan Akuntansi, 2(2).

Sudaryanto. (2014). Strategi Pemberdayaan UMKM Menghadapi Pasar Bebas Asean. Www.Kemenkeu.Go.Id, 1-32. https://doi.org/10.9790/0853-14488791

Sudaryanto dan Hanim, A. (2002). Evaluasi kesiapan UKM Menyongsong Pasar Bebas Asean(AFTA). Analisis Perspektif Dan Tinjauan Teoritis. Jurnal Ekonomi Akuntansi Dan Manajemen, 1(2).

Supriyono, R. A. (1999). Manajemen Biaya Suatu Reformasi Pengelolaan Bisnis, Buku 1. Edisi Pertama, BPFE. Yogyakarta.

Susilawati, C., \& Anton, F. X. (2009). Akuntansi Biaya, Penentuan dan Pengendalian Biaya Produk. Grasindo: Jakarta.

Tunggal, A. W. (1993). Manajemen Suatu Pengantar. Jakarta: Rineka Cipta.

Wijayanti, R. (n.d.). Penerapan Activity-Based Costing System untuk Menentukan Harga Pokok Produksi pada PT. Industri Sandang Nusantara Unit Patal Secang. Kajian Pendidikan Akuntansi Indonesia, $1(2)$. 